\title{
Biological capacity and chemical composition of secondary metabolites from representatives Japanese Lichens
}

\author{
Eman F. Ahmed ${ }^{1 *}$, Waill A. Elkhateeb ${ }^{1,2}$, Hanan A. A. Taie ${ }^{3}$, Mostafa E. Rateb ${ }^{4,5}$, Walid Fayad ${ }^{6}$ \\ ${ }^{1}$ Chemistry of natural and microbial products, National Research Centre, Dokki, Giza, 12622, Egypt. ${ }^{2}$ Laboratory of Microbial Technology Department of \\ Bioscience and Biotechnology. Faculty of Agriculture, Kyushu University. ${ }^{3}$ Department of Plant Biochemistry-National Research Centre, Dokki, Cairo, \\ Egypt. ${ }^{4}$ Pharmacognosy Department, Faculty of Pharmacy, Beni-Suef University, Beni-Suef 62514, Egypt. ${ }^{5}$ School of Science \& Sport, University of the \\ West of Scotland, Paisley PA1 2BE, UK. ${ }^{6}$ Drug Bioassay-Cell Culture Laboratory, Pharmacognosy Department, National Research Centre, Dokki, Giza, \\ 12622, Egypt.
}

\section{ARTICLE INFO}

Article history:

Received on: 05/08/2016

Revised on: 25/08/2016

Accepted on: 27/09/2016

Available online: 31/01/2017

Key words:

Lichens, Antioxidant, Cytotoxicity, (LC-HRMS), Terpene, Tannins.

\begin{abstract}
Lichens represent a well-known symbiotic system. Brachythecium velutinum (Brown), Brachythecium rutabulum, Lepraria incana, Brachythecium velutinum (Green) and Dirinaria applanata were collected from the tree trunks and rocks in Japanese forests. The alcoholic extracts of these lichens were examined for their antioxidant and cytotoxicity effect. Dirinaria applanata methanolic extract $(2.5 \mathrm{mg}$ $/ \mathrm{mL}^{-1}$ ) was the most active in scavenging DPPH free radical $(75.09 \pm 0.37 \%)$ and in reducing $\mathrm{Fe}^{3+} /$ ferricyanide complex to the ferrous form (1.88 \pm 0.03$)$. It was also the most potent in $\mathrm{ABTS}^{\circ+}$ scavenging activity using ABTS assay $89.35 \%)$ at a concentration $\left(0.5 \mathrm{mg} \cdot \mathrm{mL}^{-1}\right)$. Brachythecium rutabulum and Dirinaria applanata extracts demonstrated a significant in vitro cytotoxic effect on 549 human lung carcinoma cell line with $\mathrm{IC}_{50}$ values $(34.7 \pm 2.1$ and $38.6 \pm 2.8) \mu \mathrm{g} / \mathrm{mL}$, respectively. Dereplication of these extracts using LC-HRMS was performed to gain insight about secondary metabolism profiles of these lichens and their rule in the antioxidant and cytotoxic activities.
\end{abstract}

\section{INTRODUCTION}

Lichens are considered as a well-known symbiotic relationship between algae and fungi. They can grow on rocks and exist as epiphytes on trees and leaves (Fabian et al., 2005).Most of lichens are terrestrial and few are marine with the ability to adapt water and saline stress, extreme temperature and air pollutants (Nash, 2008). Interactions between the symbiotic partners explain this spectacular success of lichens in unusual environments (Bac ${ }^{`}$ kor and Fahselt, 2008). This symbiotic system was used in food industry and as a drug for different human diseases.

\footnotetext{
* Corresponding Author

Eman Ahmed, Chemistry of natural and microbial products, National Research Centre, Dokki, Giza, 12622, Egypt.

Email: shadydada1234 @ hotmail.com,Phone:002-0100920316.
}

Biological valuation of secondary metabolites from lichens indicated that they were produced as a defense compounds to protect themselves against microbes and other predators.

Lichens are known to produce aliphatic and aromatic compounds of low molecular weight (Türket al., 2003) which are unique to the lichen-forming fungi and accumulate either in the cortex such as atranorin, parietin, usnic acid, and fungal melanins or the medulla such as physodic acid, physodalic acid To the best of our knowledge, the biological potential of many lichens has been unexplored, for this concept we aimed to estimate the antioxidant activity and the cytotoxicity of five different lichens collected from Japanese forests as well as tentative identification of the chemical profile of each species using liquid chromatograph coupled to high resolution mass spectrometer (LC-HRMS)to gain insight about secondary metabolism profiles of these lichens and their rule in the screened biological activities. 


\section{MATERIALS AND METHODS}

\section{Collection and extraction of Samples}

Lichens were collected from the trees and rocks of Kashiihama Higashi-ku Fukuoka-shi and Hakozaki Higashi-ku Fukuoka-shi forests in Japan and were identified by Lichenological Society of Japan (http://eng.lichenjapan.jp/? page_id=23). Samples were washed with running distilled water and dried. About 500 grams of each specimen were undergone extraction by the use of $80 \%$ methanol. The extracts were dried under vacuum by the rotatory evaporator and weighed.

\section{LC-HRMS analysis}

High resolution mass spectral data was obtained from a Thermo Instruments MS system (Finnigan LTQ / LTQ Orbitrap) coupled to a Thermo Instruments HPLC system (Accela PDA detector, Accela PDA autosampler and Accela Pump). The following conditions were used: capillary voltage $45 \mathrm{~V}$, capillary temperature $260^{\circ} \mathrm{C}$, auxiliary gas flow rate 10-20 arbitrary units, sheath gas flow rate 40-50 arbitrary units, spray voltage $4.5 \mathrm{kV}$, mass range 100-2000 amu (maximum resolution 60000). Gradient separation was achieved using a Poroshell EC-C18 RP analytical HPLC column $(2.7 \mu \mathrm{m}, 2.1 \times 100 \mathrm{~mm}$, Agilent, USA $)$ with a mobile phase of $0-100 \% \mathrm{MeCN}$ over 25 min followed by $100 \%$ $\mathrm{MeCN}$ over $10 \mathrm{~min}$ at a flow rate of $0.5 \mathrm{~mL} / \mathrm{min}$.

\section{Cytotoxicity \\ Cell culture}

A human lung carcinoma cell line (A549) was maintained in RPMI-1640 media, supplemented with $10 \%$ fetal bovine serum and antibiotic-antimycotic mixture. The cell line was cultured in $95 \%$ humidity, $5 \% \mathrm{CO}_{2}$ and $37^{\circ} \mathrm{C}$.

\section{Cytotoxicity test}

5000 cells were seeded per well in 96 well plates, left to attach overnight, and then treated with samples for three days. Extracts were tested at 250, 125, 62.5, 31.2, 15.6, 7.8, 3.9 and 1.9 $\mu \mathrm{g} / \mathrm{mLfinal}$ concentrations. Staurosporine $(2 \mu \mathrm{M})$ was used as positive control and $0.5 \%$ DMSO was used negative control. Cell cytotoxicity was determined using the MTT [3-(4,5dimethylthiazol-2-yl)-2,5-diphenyltetrazolium bromide] assay as described by Mosmann 1983.

In brief, medium was aspirated, $40 \mu \mathrm{l}$ MTT salt $(2.5 \mu \mathrm{g} / \mathrm{mL})$ were added to each well and incubated for further $4 \mathrm{~h}$. To stop the reaction and dissolve the formed crystals, $150 \mu$ Lof $10 \%$ Sodium dodecyl sulphate (SDS) in deionized water was added to each well and incubated overnight at $37^{\circ} \mathrm{C}$. The absorbance was then measured at $595 \mathrm{~nm}$ and a reference wavelength of $690 \mathrm{~nm}$.The equation used for calculation of percentage cytotoxicity was:

$$
[1-(\operatorname{av}(\mathrm{X})) /(\operatorname{av}(\mathrm{NC}))]^{*} 100
$$

Where: av: average, X: absorbance of test extract, NC: absorbance of negative control.
$\mathrm{IC}_{50}$ values were determined by SPSS computer program (SPSS for windows, statistical analysis software package / version 9 / 1989 SPSS Inc., Chicago, USA).

\section{Antioxidant potential Antioxidant Activity (DPPH Assay)}

The free radical scavenging activity using the 1.1diphenyl-2-picryl- hydrazil (DPPH) reagent was determined according to Brand-Williams et al. (1995). Several concentrations of the collected Lichens methanol extracts $(0.5,1.0,1.5,2.0$ and $2.5 \mathrm{mg} / \mathrm{mL}$ ) were added to1.0 mLof freshly prepared methanolic DPPH solution $\left(20 \mu \mathrm{g} . \mathrm{mL}^{-1}\right)$ and stirred. The decolorizing process was recorded after $5 \mathrm{~min}$ of reaction at $517 \mathrm{~nm}$ and compared with a blank control.

Antioxidant activity $=[($ control absorbance - sample absorbance $) /$ Control absorbance $] \times 100 \%$

\section{Reducing power Assay}

The reducing power of lichen extracts were evaluated according to the method of Oyaizu, (1986). 0.5mLof different concentrations $(0.5,1.0,1.5,2.0$ and $2.5 \mathrm{mg} / \mathrm{ml})$ methanol extracts were added to Phosphate buffer ( $2.5 \mathrm{~mL}, 0.2 \mathrm{M}, \mathrm{pH} 6.6)$ and $1 \%$ potassium ferricyanide $(2.5 \mathrm{~mL})$. The mixture was incubated at $50^{\circ} \mathrm{C}$ for $20 \mathrm{~min}$. Aliquots of trichloroacetic acid $(2.5 \mathrm{~mL}, 10 \%)$ were added to the mixture, which was then centrifuged at 1000 $\mathrm{rpm}$ for $10 \mathrm{~min}$. The upper layer of solution $(2.5 \mathrm{~mL})$ was mixed with distilled water $(2.5 \mathrm{~mL})$ and a freshly prepared $\mathrm{FeCl}_{3}$ solution $(0.5 \mathrm{~mL}, 0.1 \%)$. The absorbance was measured at $700 \mathrm{~nm}$. Increased absorbance of their action mixture indicated increased reducing power.

\section{2,2'-azino-bis(3-ethylbenzothiazoline-6-sulphonic acid) ABTS radical scavenging assay}

The method of Re et al. (1999) was investigated. The stock solutions included $7 \mathrm{mM}$ ABTS solution and $2.4 \mathrm{mM}$ potassium persulfate solution. The working solution was prepared by mixing the two stock solutions in equal quantities and allowing them to react for $12 \mathrm{~h}$ at room temperature in the dark. The solution was then diluted by mixing $1 \mathrm{~mL} \mathrm{ABTS}^{+4}$ solution with 60 $\mathrm{mL}$ methanol to obtain an absorbance of $0.706 \pm 0.001$ units at 734 $\mathrm{nm}$ using the spectrophotometer. $\mathrm{ABTS}^{++}$Solution was freshly prepared for each assay. $0.150 \mathrm{~mL}$ of each extract $(0.1,0.2,0.3,0.4$ and 0.5$) \mathrm{mg} / \mathrm{mL}$ of sample 1,4 and 5 while $(0.5,1.00,1.5,2.00$ and 2.5) $\mathrm{mg} / \mathrm{mL}$ of samples 2 and 3 were allowed to react with 2850 $\mu \mathrm{L}$ of the $\mathrm{ABTS}^{++}$Solution and the absorbance were taken at 734 $\mathrm{nm}$ after $7 \mathrm{~min}$ using the spectrophotometer. The $\mathrm{ABTS}^{+}$ scavenging capacity of the extract and isolated compounds percentage inhibition calculated as ABTS radical scavenging activity.

$$
\left.(\%)=\left[\left(\mathrm{Abs}_{\text {control }}-\mathrm{Abs}_{\text {sample }}\right)\right] /\left(\mathrm{Abs}_{\text {control }}\right)\right] \times 100
$$

Where $\mathrm{Abs}_{\text {control }}$ the absorbance of ABTS radical + methanol; Abs.sample is the absorbance of ABTS radical + sample extract. 


\section{Ferric reducing antioxidant power assay (FRAP)}

The FRAP assay was done according to Benzie and Strain (1999) with some modifications. The stock solutions included $300 \mathrm{mM}$ acetate buffer, pH 3.6, $10 \mathrm{mM}$ TPTZ (2, 4, 6tripyridyl-s-triazine) solution in $40 \mathrm{mM} \mathrm{HCl}$, and $20 \mathrm{mM}$ $\mathrm{FeCl}_{3} \cdot 6 \mathrm{H}_{2} \mathrm{O}$ solution. The fresh working solution was prepared by mixing $25 \mathrm{~mL}$ acetate buffer, $2.5 \mathrm{mLTPTZ}$ solution, and $2.5 \mathrm{mLFeCl}_{3} \cdot 6 \mathrm{H}_{2} \mathrm{O}$ solution and then warmed at $37^{\circ} \mathrm{C}$ before using. $150 \mu$ Lof lichens methanol extracts $(0.5,1.00,1.5,2.00$ and $2.5 \mathrm{mg} / \mathrm{mL}$ ) were allowed to react with $2850 \mu$ Lof the FRAP solution for $30 \mathrm{~min}$ in the dark condition. Readings of the colored product [ferrous tripyridyltriazine complex] were then taken at $593 \mathrm{~nm}$. Results are expressed in $\mu \mathrm{mol}$ Trolox /100 g dry matter. Additional dilution was needed if the FRAP value measured was over the linear range of the standard curve.

\section{RESULTS AND DISCUSSION}

Lichens used in this study were collected from different Japanese forest as presented in Table 1 .

Table 1: The collected and identified lichens.

\begin{tabular}{cc}
\hline Number & Lichen \\
\hline 1 & Brachythecium velutinum (Brown) \\
2 & Brachythecium rutabulum \\
3 & Lepraria incana \\
4 & Brachythecium velutinum (Green) \\
5 & Dirinaria applanata \\
\hline
\end{tabular}

\section{Cytotoxicity}

The cytotoxic effect of the five lichen extracts was evaluated on A549 human lung carcinoma cell line. Staurosporine $(2 \mu \mathrm{M})$ was used as positive control and $0.5 \%$ DMSO was used negative control. Our results showed that these extracts had a cytotoxic potential at all concentrations and the sensitivity of the treated lung cells was maximum at the highest concentration. Significant cytotoxic effect was clearly obtained by treatment with Brachythecium reticulum extract which exhibited $\mathrm{IC}_{50}$ value of $34.7 \pm 2.1 \mu \mathrm{g} / \mathrm{mL}$ Followed by that of Dirinaria applanata which showed $\mathrm{IC}_{50}$ value of $38.6 \pm 2.8 \mu \mathrm{g} / \mathrm{mL}$, table(2). This could be attributed to the presence of terpenes, flavonoids and alkaloids, chemical classes of natural products which had proven record of strong cytotoxic effects based on the LCMS analysis of these lichens.

Table 2: Cytotoxic effect of lichens alcoholic extract.

\begin{tabular}{lc}
\hline \multicolumn{1}{c}{ Lichen name } & $\mathbf{I C}_{\mathbf{5 0}}(\boldsymbol{\mu} \mathbf{g} / \mathbf{m L})$ \\
\hline 1.Brachytheciumvelutinum(Brown) & $132.4 \pm 5.7$ \\
2.Brachytheciumrutabulum & $34.7 \pm 2.1$ \\
3. Leprariaincana & $43.7 \pm 3.9$ \\
4.Brachytheciumvelutinum(Green) & $57.3 \pm 4.5$ \\
5.Dirinariaapplanata & $38.6 \pm 2.8$ \\
\hline
\end{tabular}

\section{Antioxidant capacity}

\section{DPPH free radical scavenging activity}

The antioxidant activity of the methanol extract of these lichens was measured in terms of hydrogen-donating or radical- scavenging ability, using the stable DPPH as reagent. The results, presented in figure 1 revealed the variability in antioxidant capability of the examined samples .Of the five tested samples, only sample 2 and 3 did not demonstrate good antioxidant activity. All the other samples exhibited good antioxidant activity specially sample 5 which showed about $75.09 \pm 0.37 \%$ at the concentration $2.5 \mathrm{mg} / \mathrm{mL}$. This activity was gradually decreased to $40.74 \pm 1.04 \%$ at a concentration of $0.5 \mathrm{mg} / \mathrm{mL}$. All the samples exhibited significant dose dependent inhibition of DPPH activity. Many human diseases such as neurodegenerative, cardiovascular and diabetes are developed pathologically by reactive oxygen species. Due to their antioxidant behavior, terpenes have been shown to provide relevant protection under oxidative stress conditions in different diseases. The identified terpenes such as Bufotalin, Dantaxusin A, moreollic acid, taxuspine B Suberixanthin, Gaigrandin, ergosteryl acetate and dichrostachine Fin Dirinaria applanata, Brachythecium velutinum (Green) and Brachythecium velutinum (Brown) could be related to this strong antioxidant potential through free radical scavenging mechanisms(GonzálezBurgos and Gómez-Serranillos 2012).

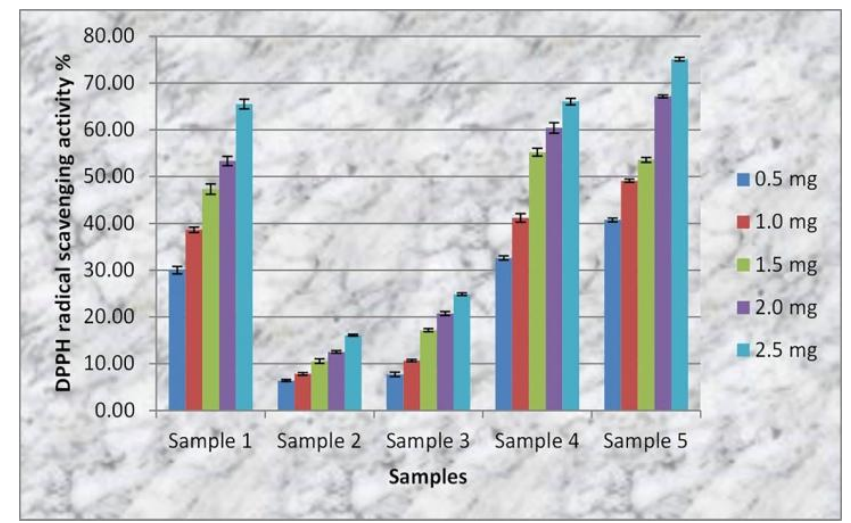

Fig. 1: DPPH radical scavenging activity of methanol extracts of lichens at different concentrations.Each value represents the mean of three replicates (Mean $\pm \mathrm{SD}$ ).

\section{Reducing power capability}

Reducing agents provide electrons to the reduced species. The presence of these molecules such as antioxidant substances in the screened samples causes the reduction of the $\mathrm{Fe}^{3+} /$ ferricyanide complex to the ferrous form. The yellow color of the test solution changes to various shades of green and blue depending on the reducing power of antioxidant samples. Therefore, $\mathrm{Fe}^{2+}$ can be monitored by measuring the formation of Perl's Prussian blue at $700 \mathrm{~nm}$ (Chung et al., 2002). Figure 2 depicted the reducing activity of the methanol extracts of lichens. Reducing power capability increased gradually by increasing the concentration of each extract. The reducing power capability of sample 2 found to be the least among all tested samples and ranged from $0.16 \pm 0.02$ to $0.61 \pm 0.05$ at the concentrations 0.5 and $2.5 \mathrm{mg} / \mathrm{mL}$, respectively. On the contrary sample 5 exhibited the highest reducing capability in an ascending manner with values of $0.97 \pm 0.02,1.17 \pm 0.01,1.39 \pm 0.02,1.72 \pm 0.09$ and $1.88 \pm 0.03$ at the concentrations $0.5,1.00,1.5,2.00$ and $2.5 \mathrm{mg} / \mathrm{mL}$, respectively. 
This could be attributed to the presence of tannins in Dirinaria applanata extract such asellagic acid 3, 3'-di-O-methyl ether, 5, 5'dehydrodiferulic acid, and 3, 3', 4-tri-O-methylellagic acid. Tannins do not function as primary antioxidants (i.e., they donate hydrogen atom or electrons), but they could be considered as secondary antioxidants. Tannins are able to chelate the metal $\mathrm{Fe}$ (II) and interfere with one of the reaction steps and thereby impede oxidation (Karamac'et al., 2006).

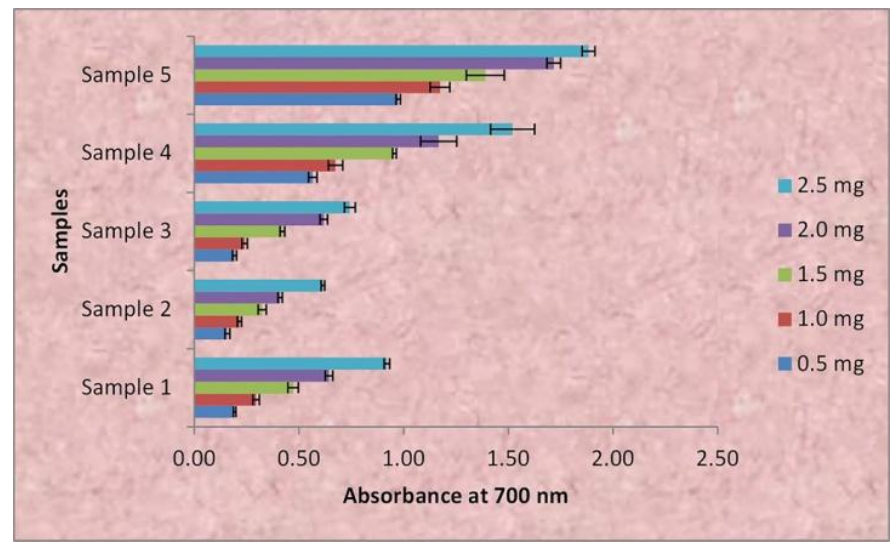

Fig. 2: Reducing power capability of the methanol extracts of lichens at different concentrations. Each value represents the mean of three replicates (Mean \pm SD).

\section{ABTS Radical scavenging activity}

Excessive formation of free radicals accelerates the oxidation of lipids in foods and decreases food quality and consumer acceptance (Min, 1998). Hence, radical scavenging activities are very important due to the deleterious role of free radicals in foods and in biological systems. A more appropriate format for the assay is a decolonization technique in that the radical is generated directly in a stable form prior to reaction with putative antioxidants. The improved technique for the generation of $\mathrm{ABTS}^{\circ+}$ described here involves the direct production of the blue/green $\mathrm{ABTS}^{\circ+}$ chromophore through the reaction between $\mathrm{ABTS}^{++}$and potassium persulfate. As seen in figure 3, several concentrations were used foreach methanol extract of lichens to determine the radical scavenging activity using ABTS assay.

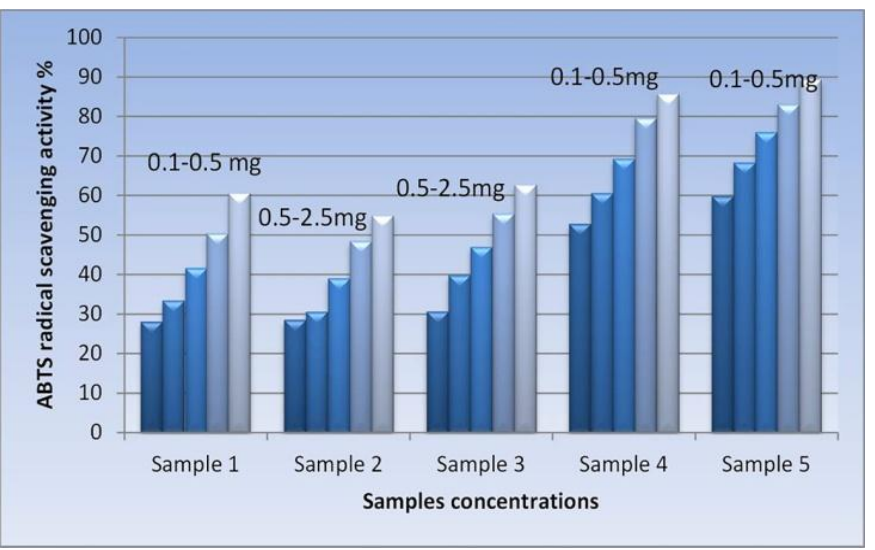

Fig. 3: Scavenging effect of the methanol extracts of lichens on the $\mathrm{ABTS}^{\cdot+}$ at different concentrations.
Sample 5 had the highest radical scavenging activity which showed 59.92, 68.36, 76.07, 83.11 and $89.35 \%$ at the concentrations of $0.1,0.2,0.3,0.4$ and $0.5 \mathrm{mg} / \mathrm{mL}$, respectively. Similar results were obtained in sample 4 , it possessed high radical scavenging activity of $85.78 \%$ at the concentration $0.5 \mathrm{mg} / \mathrm{mL}$. Moderate radical scavenging activities of 60.65 and $62.77 \%$ were found at the high concentration of sample 1 and $3(0.1 \mathrm{mg} / \mathrm{mL})$, respectively.

\section{Ferric reducing antioxidant power (FRAP)}

The FRAP test was used to measure the total antioxidant capacity of lichens. Method is based on electron transfer and is regarded as accurate indicators of total antioxidant power, since total reducing power is defined as the sum of the reducing powers of the individual compounds contained in a particular sample (Tezcan et al., 2011). FRAP activity of samples is given in figure 4.All the investigated samples exhibited ferric reducing antioxidant power and their activity increased in a dose dependent manner with the increase in the concentration. Sample 5 and 4 exhibited the highest ferric reducing antioxidant power which ranged from 2105 to $3830 \mu \mathrm{M}$ TEAC/ $100 \mathrm{~g}$ at 0.5 to $2.5 \mathrm{mg} / \mathrm{mL}$ and from 2242 to $3424 \mu \mathrm{M}$ TEAC/ $100 \mathrm{~g}$ at 0.5 to $2.5 \mathrm{mg} / \mathrm{mL}$ for samples 5 and 4, respectively. Results also indicated that sample 2 had the lowest ferric reducing antioxidant power at $1543 \mu \mathrm{M}$ TEAC/100g at the highest concentration $(2.5 \mathrm{mg} / \mathrm{mL})$.

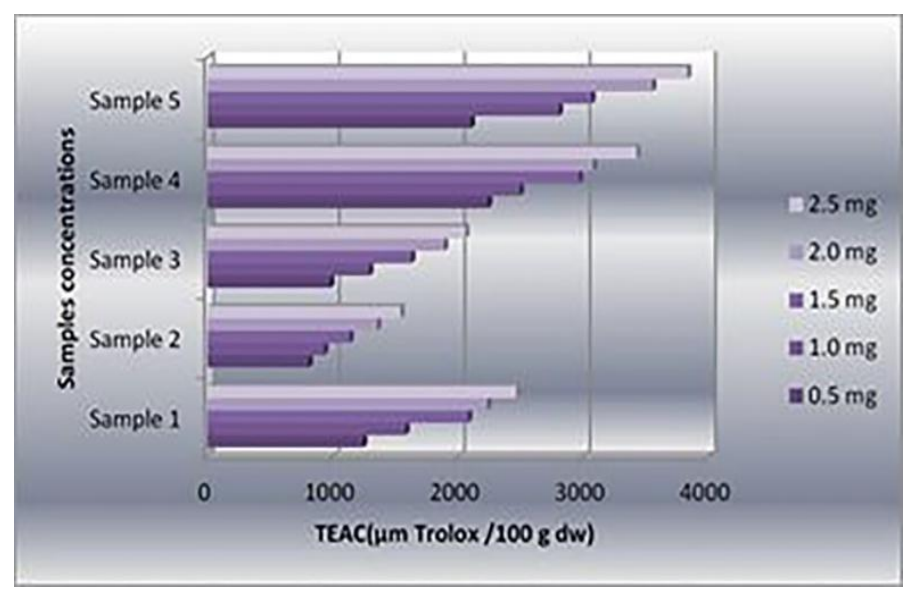

Fig. 4: Ferric Reducing antioxidant property (FRAP) of the methanol extracts of lichens at different concentrations.

\section{LC-HRESIMS analysis of the methanolic extract of lichens}

The LC-HRMS analysis of the methanolic extract of Lichens (Table 3 and Figure 5) indicated the presence of a range of secondary metabolites with different chemical classes ranging fromnon-polar steroids and terpenes to the polar flavonoids and tannins. Most of the identified metabolites previously showed moderate to strong cytotoxic and antioxidant activities. 


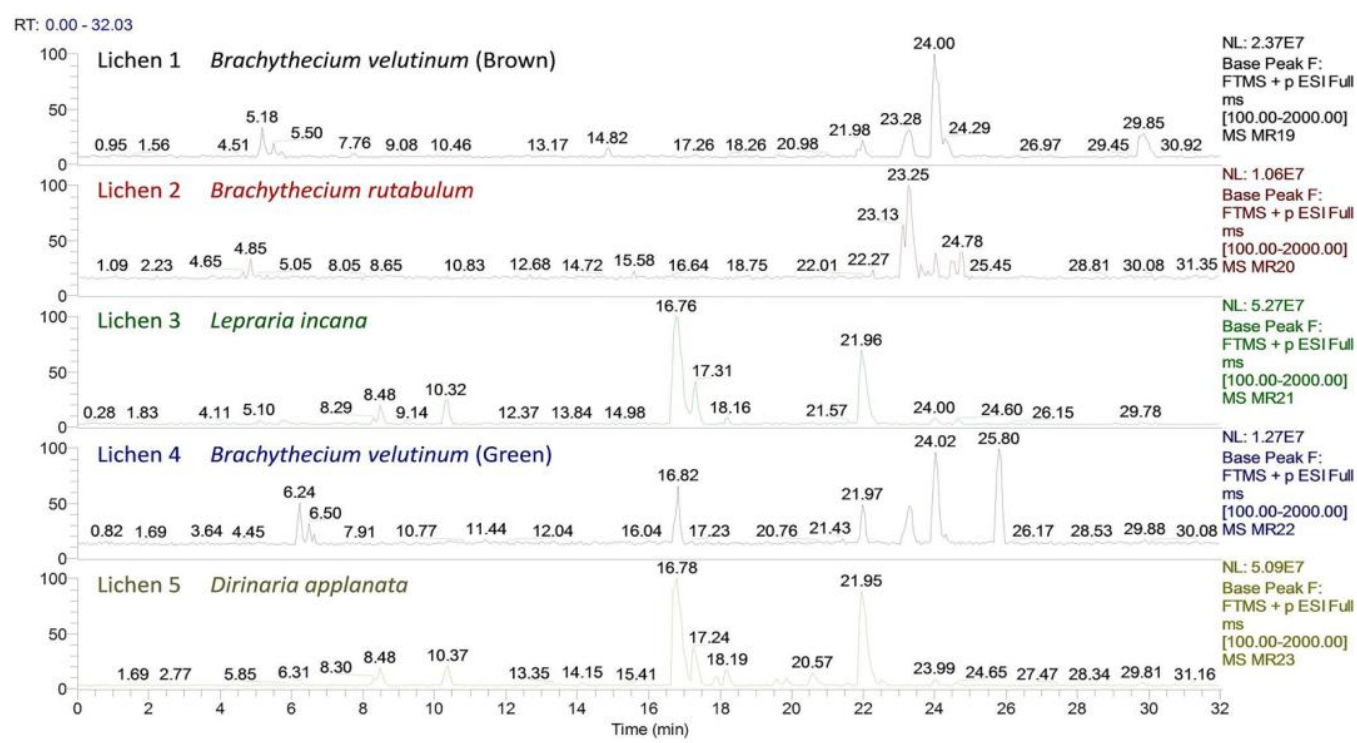

Fig. 5: LC-HRESIMS analysis of the methanolic extract of lichens.

Table 3: LC-HRESIMS analysis of the methanolic extract of lichens.

\begin{tabular}{|c|c|c|c|c|}
\hline Rt min & $m / z$ Experimental & Selected ion & Formula $^{\mathrm{a}}$ & Suggested Compound $^{\mathrm{b}}$ \\
\hline \multicolumn{5}{|c|}{ Lichen 1: Brachytheciumvelutinum (Brown) } \\
\hline 5.18 & 465.1016 & {$[\mathrm{M}+\mathrm{H}]^{+}$} & $\mathrm{C}_{21} \mathrm{H}_{20} \mathrm{O}_{12}$ & Hyperoside (Flavonoid glycoside) \\
\hline 5.50 & 303.0488 & {$[\mathrm{M}+\mathrm{H}]^{+}$} & $\mathrm{C}_{1}{ }_{5} \mathrm{H}_{10} \mathrm{O}_{7}$ & Robinetin (Flavonoid aglycone) \\
\hline 5.70 & 287.0542 & {$[\mathrm{M}+\mathrm{H}]^{+}$} & $\mathrm{C}_{15} \mathrm{H}_{10} \mathrm{O}_{6}$ & Scutellarein (Flavonoid aglycone) \\
\hline 14.82 & 445.2548 & {$[\mathrm{M}+\mathrm{H}]^{+}$} & $\mathrm{C}_{26} \mathrm{H}_{36} \mathrm{O}_{6}$ & Bufotalin (Terpene) \\
\hline 21.85 & 621.2695 & {$[\mathrm{M}+\mathrm{H}]^{+}$} & $\mathrm{C}_{35} \mathrm{H}_{40} \mathrm{O}_{10}$ & Dantaxusin A (Terpene) \\
\hline 21.98 & 593.2745 & {$[\mathrm{M}+\mathrm{H}]^{+}$} & $\mathrm{C}_{34} \mathrm{H}_{40} \mathrm{O}_{9}$ & moreollic acid (Terpene) \\
\hline 23.28 & 623.2853 & {$[\mathrm{M}+\mathrm{H}]^{+}$} & $\mathrm{C}_{35} \mathrm{H}_{42} \mathrm{O}_{10}$ & taxuspine B (Terpene) \\
\hline 24.00 & 607.2901 & {$[\mathrm{M}+\mathrm{H}]^{+}$} & $\mathrm{C}_{35} \mathrm{H}_{42} \mathrm{O}_{9}$ & taxuspine $\mathrm{C}$ (Terpene) \\
\hline 24.29 & 547.2692 & {$[\mathrm{M}+\mathrm{H}]^{+}$} & $\mathrm{C}_{33} \mathrm{H}_{38} \mathrm{O}_{7}$ & Dihydroisomorellin (Terpene) \\
\hline \multicolumn{5}{|c|}{ Lichen 2: Brachytheciumrutabulum } \\
\hline 4.85 & 325.0698 & {$[\mathrm{M}+\mathrm{H}]^{+}$} & $\mathrm{C}_{18} \mathrm{H}_{12} \mathrm{O}_{6}$ & Sterigmatocystine (xanthene) \\
\hline 23.13 & 639.2798 & {$[\mathrm{M}+\mathrm{H}]^{+}$} & $\mathrm{C}_{35} \mathrm{H}_{42} \mathrm{O}_{11}$ & propinquanin B (polyketide) \\
\hline 23.25 & 623.2853 & {$[\mathrm{M}+\mathrm{H}]^{+}$} & $\mathrm{C}_{35} \mathrm{H}_{42} \mathrm{O}_{10}$ & taxuspine $\mathrm{B}$ (Terpene) \\
\hline 24.00 & 607.2901 & {$[\mathrm{M}+\mathrm{H}]^{+}$} & $\mathrm{C}_{35} \mathrm{H}_{42} \mathrm{O}_{9}$ & taxuspine $\mathrm{C}$ (Terpene) \\
\hline 24.50 & 653.2955 & {$[\mathrm{M}+\mathrm{H}]^{+}$} & $\mathrm{C}_{36} \mathrm{H}_{44} \mathrm{O}_{11}$ & schisantherin I (polyketide) \\
\hline 24.78 & 661.4631 & {$[\mathrm{M}+\mathrm{H}]^{+}$} & $\mathrm{C}_{39} \mathrm{H}_{64} \mathrm{O}_{8}$ & Tetrahydroxyoleanenoic-acid $28-O-\beta$-D-glucopyranosyl ester (Terpene) \\
\hline \multicolumn{5}{|c|}{ Lichen 3: Leprariaincana } \\
\hline 8.29 & 331.0438 & {$[\mathrm{M}+\mathrm{H}]^{+}$} & $\mathrm{C}_{16} \mathrm{H}_{10} \mathrm{O}_{8}$ & ellagic acid 3,3'-di-O-methyl ether (tannin) \\
\hline 8.48 & 387.1065 & {$[\mathrm{M}+\mathrm{H}]^{+}$} & $\mathrm{C}_{20} \mathrm{H}_{18} \mathrm{O}_{8}$ & 5,5'-dehydrodiferulic acid (tannin) \\
\hline 10.32 & 345.0596 & {$[\mathrm{M}+\mathrm{H}]^{+}$} & $\mathrm{C}_{17} \mathrm{H}_{12} \mathrm{O}_{8}$ & 3,3',4-tri-O-methylellagic acid (tannin) \\
\hline 16.76 & 389.1587 & {$[\mathrm{M}+\mathrm{H}]^{+}$} & $\mathrm{C}_{21} \mathrm{H}_{24} \mathrm{O}_{7}$ & 5'-methoxydehydrodiconiferyl alcohol (tannin) \\
\hline 17.31 & 620.4150 & {$[\mathrm{M}+\mathrm{H}]^{+}$} & $\mathrm{C}_{35} \mathrm{H}_{57} \mathrm{NO}_{8}$ & pavoninin-2 (terpene) \\
\hline 20.57 & 571.3073 & {$[\mathrm{M}+\mathrm{H}]^{+}$} & $\mathrm{C}_{36} \mathrm{H}_{42} \mathrm{O}_{6}$ & terpecurcumin Q (terpene) \\
\hline 21.95 & 439.3565 & {$[\mathrm{M}+\mathrm{H}]^{+}$} & $\mathrm{C}_{30} \mathrm{H}_{46} \mathrm{O}_{2}$ & ergosteryl acetate (terpene) \\
\hline 24.00 & 607.2903 & {$[\mathrm{M}+\mathrm{H}]^{+}$} & $\mathrm{C}_{35} \mathrm{H}_{42} \mathrm{O}_{9}$ & taxuspine $\mathrm{C}$ (Terpene) \\
\hline 24.60 & 567.4009 & {$[\mathrm{M}+\mathrm{H}]^{+}$} & $\mathrm{C}_{36} \mathrm{H}_{54} \mathrm{O}_{5}$ & lantadene A methyl ester (Terpene) \\
\hline \multicolumn{5}{|c|}{ Lichen 4: Brachytheciumvelutinum(Green) } \\
\hline 6.24 & 365.2061 & {$[\mathrm{M}+\mathrm{H}]^{+}$} & $\mathrm{C}_{24} \mathrm{H}_{28} \mathrm{O}_{3}$ & ugonstilbene A (Phenolic) \\
\hline 6.50 & 366.1903 & {$[\mathrm{M}+\mathrm{H}]^{+}$} & $\mathrm{C}_{19} \mathrm{H}_{27} \mathrm{NO}_{6}$ & harzianic acid (Alkaloid) \\
\hline 16.82 & 389.1587 & {$[\mathrm{M}+\mathrm{H}]^{+}$} & $\mathrm{C}_{21} \mathrm{H}_{24} \mathrm{O}_{7}$ & 5'-methoxydehydrodiconiferyl alcohol (tannin) \\
\hline 21.97 & 593.2745 & {$[\mathrm{M}+\mathrm{H}]^{+}$} & $\mathrm{C}_{34} \mathrm{H}_{40} \mathrm{O}_{9}$ & moreollic acid (Terpene) \\
\hline 23.25 & 623.2853 & {$[\mathrm{M}+\mathrm{H}]^{+}$} & $\mathrm{C}_{35} \mathrm{H}_{42} \mathrm{O}_{10}$ & taxuspine $\mathrm{B}$ (Terpene) \\
\hline 24.02 & 607.2903 & {$[\mathrm{M}+\mathrm{H}]^{+}$} & $\mathrm{C}_{35} \mathrm{H}_{42} \mathrm{O}_{9}$ & taxuspine $\mathrm{C}$ (Terpene) \\
\hline 25.80 & 593.4369 & {$[\mathrm{M}+\mathrm{H}]^{+}$} & $\mathrm{C}_{42} \mathrm{H}_{56} \mathrm{O}_{2}$ & Suberixanthin (Terpene) \\
\hline \multicolumn{5}{|c|}{ Lichen 5: Dirinariaapplanata } \\
\hline 8.30 & 331.0438 & {$[\mathrm{M}+\mathrm{H}]^{+}$} & $\mathrm{C}_{16} \mathrm{H}_{10} \mathrm{O}_{8}$ & ellagic acid 3,3'-di-O-methyl ether (tannin) \\
\hline 8.48 & 387.1065 & {$[\mathrm{M}+\mathrm{H}]^{+}$} & $\mathrm{C}_{20} \mathrm{H}_{18} \mathrm{O}_{8}$ & 5,5'-dehydrodiferulic acid (tannin) \\
\hline 10.37 & 345.0596 & {$[\mathrm{M}+\mathrm{H}]^{+}$} & $\mathrm{C}_{17} \mathrm{H}_{12} \mathrm{O}_{8}$ & 3,3',4-tri-O-methylellagic acid (tannin) \\
\hline 16.78 & 389.1587 & {$[\mathrm{M}+\mathrm{H}]^{+}$} & $\mathrm{C}_{21} \mathrm{H}_{24} \mathrm{O}_{7}$ & 5'-methoxydehydrodiconiferyl alcohol (tannin) \\
\hline 18.19 & 425.2134 & {$[\mathrm{M}+\mathrm{H}]^{+}$} & $\mathrm{C}_{22} \mathrm{H}_{32} \mathrm{O}_{8}$ & Gaigrandin (terpene) \\
\hline 20.57 & 571.3073 & {$[\mathrm{M}+\mathrm{H}]^{+}$} & $\mathrm{C}_{36} \mathrm{H}_{42} \mathrm{O}_{6}$ & terpecurcumin Q (terpene) \\
\hline 21.95 & 439.3565 & {$[\mathrm{M}+\mathrm{H}]^{+}$} & $\mathrm{C}_{30} \mathrm{H}_{46} \mathrm{O}_{2}$ & ergosteryl acetate (terpene) \\
\hline 23.99 & 607.2903 & {$[\mathrm{M}+\mathrm{H}]^{+}$} & $\mathrm{C}_{35} \mathrm{H}_{42} \mathrm{O}_{9}$ & taxuspine $\mathrm{C}$ (Terpene) \\
\hline 24.65 & 621.3057 & {$[\mathrm{M}+\mathrm{H}]^{+}$} & $\mathrm{C}_{36} \mathrm{H}_{44} \mathrm{O}_{9}$ & dichrostachine $\mathrm{F}$ (Terpene) \\
\hline
\end{tabular}

${ }^{a}$ The molecular formula was deducted from the accurate mass analysis of the metabolite profile using Xcalibur 3.0 software. ${ }^{b}$ The suggested compound based on dereplication using the Dictionary of Natural Product database Version 23.1 on DVD and by comparison with the fragmentation pattern with literature data when applicable. 


\section{CONCLUSION}

Lichens represent a well-known symbiotic relationship between algae and fungi which is successfully used in food industry and for different human diseases. Lichens tend to produce secondary metabolites as a defense mechanism to protect themselves against external predators. In this study, lichens were collected from Japanese forests and their alchoholic extracts were screened for their potential antioxidant and cytotoxic effects. The methanolic extract of Dirinaria applanata was the most potent which exhibited a significant antioxidant effect towards different radicals by the application of different assays. Additionally, the methanolic extract of Brachythecium rutabulum and Dirinaria applanata considered the most cytotoxic among the five screened lichens against 549 human lung carcinoma cell line. This strong antioxidant activity could be attributed to reducing the prooxidant processes and enhancing the antioxidant ones by participating in the synthesis of prostaglandins and phospholipids components of cell membrane thus which could be applicable in skin protection mechanisms (Butnariu and Giuchici, 2011). Dereplication using LC-HRMS indicated the presence of a lot of known secondary metabolites belonging to different chemical classes which explains the strong antioxidant activity exhibited by these extracts (Rashed and Butnariu, 2014). Based on the LCMS analysis, these lichens were rich in terpenes, flavonoids and alkaloids, chemical classes of natural products which had proven record of strong cytotoxic effects.

This study shed the light of using such lichens as safe and effective preservatives in canned food industry and as a topical application for UV skin protection. Moreover, formulation of these extracts for nanoparticle for drug delivery (Butu et al., 2015) could be a potential point of future research which could allow in-depth study of their cytotoxic effect.

\section{ACKNOWLEDGEMENTS}

The authors would like to thank Prof. Marcel Jaspars, Marine Biodiscovery Centre, University of Aberdeen for acquiring LC-HRMS in his laboratory.

\section{Financial support and sponsorship: Nil.}

Conflict of Interests: There are no conflicts of interest.

\section{REFERENCES}

Bac `or M. and Fahselt D. Lichen photobionts and metal toxicity. Symbiosis. $2008 ; 46: 1-10$.

Benzie I.F.F and Strain, J.J. Ferric reducing, antioxidant power assay: Direct measure of total antioxidant activity of biological fluids and modified version for simultaneous measurement of total antioxidant power and ascorbic acid concentration. Methods Enzym. 1999; 299: 15-27.
Brand-Williams W., Cuvelier M.E., Berset C. Use of a free radical method to evaluate antioxidant activity. Lebensmittel Wissenschaften und Technologi. 1995; 28: 25-30.

Butu A., Rodino S., Golea D., Butu M., Butnariu M., Negoescu C., Dinu-Pîrvu C-E.Liposomal nanodelivery system for proteasome inhibitor anticancer drug bortezomib. Farmacia. 2015; 63(2): 224-229.

Chung Y.C., Chang C.T., Chao W.W., Lin C.F., Chou S.T. Antioxidative activity and safety of the $50 \%$ ethanolic extract from red bean fermented by Bacillus subtilis IMR-NK1. J. Agric. Food Chem. 2002; 50: 2454-2458.

Fabian A.S., Peter D.C., Matthew J.D., Mathieu P., Dolores M., Lily C. Paul S.D. FungalGenet. Biol. 2005; 42: 554.

González-Burgos E., Gómez-Serranillos M. Terpene compounds in nature: a review of their potential antioxidant activity. Curr Med Chem. 2012; 19(31): 5319-41.

Karamac' M. , Kosinska A.,Amarowicz R. Chelating of Fe(II), $\mathrm{Zn}$ (II) and $\mathrm{Cu}$ (II) by tannin fractions separated from hazelnuts, walnuts and almonds. BromatChemToksykol. 2006; 39: 257-260.

Min D.B. Lipid oxidation of edible oil.In Food Lipids chemistry, nutrition, and biotechnology, C.C., Akoh, D.B., Min. (Eds), Marcel Dekker, New York. 1998; 283-296.

Monica V.,Butnariu M.V., Giuchici C.V. The use of some nanoemulsions based on aqueous propolis and lycopene extract in the skin's protective mechanisms against UVA radiation, J Nanobiotechnol, 2011; 9: 3

Mosmann T. Rapid colorimetric assay for cellular growth and survival: application to proliferation and cytotoxicity assays. J Immunol Methods. 1983; 65(1-2) 55.

Nash T. H. III (ed.). Lichen Biology, 2nd ed. Cambridge University Press, Cambridge. Nelsen M. P. and Gargas A. 2008.

Oyaizu M. Studies on the product of browning reaction prepared from glucosamine. Jpn J. Nutrition. 1986; 44: 307- 315.

Rashed K. and Butnariu M. Antimicrobial and Antioxidant Activities of Bauhinia racemosa Lam. and Chemical Content, Iran J Pharm Res, 2014; 13(3): 1073-1080. Rice-Evans C.

Re R., Pellegrini N., Proteggente A., Pannala A., Yang M.,

Antioxidant activity applying an improved ABTS radical cation decolorization assay.Free Radical Biology and Medicine. 1999; 26:12311237.

Tezcan F., Kolaylı S., Sahin H., Ulusoy E., Erim B.F. Evaluation of organic acid, saccharide composition and antioxidant properties of some authentic Turkish honeys. J. Food Nutr. Res. 2011; 50: $33-40$.

Türk A.Ö, Yilmaz M., Kivanç M., Türk H. The antimicrobial activity of extracts of the lichen Cetrariaaculeata and its protolichesterinic acid constituent. Z. Naturforsch. 2003; 58c, $850-854$.

\section{How to cite this article:}

Ahmed EF, Elkhateeb WA, Taie HAA, Rateb ME, Fayad W. Biological capacity and chemical composition of secondary metabolites from representatives Japanese Lichens. J App Pharm Sci, 2017; 7 (01): 098-103. 